종 설

\author{
유기축산물 소비동향과 해결과제 \\ 김동훈 · 성필남 · 조수현 · 권두중 \\ 농촌진흥청 축산연구소
}

\title{
A Review of Emerging Trends and Critical Aspects in Organic Livestock Product Consumption
}

\author{
D. H. Kim, P. N. Seong, S. H. Cho and D. J. Kwon \\ National Livestock Research Institute, RDA
}

\begin{abstract}
There are approximately 250,000 organic livestock farming in the world. The total retail value of organic food sales in the world is $\$ 27$ billion. The organic livestock products such as milk, lamb and beef are marketed mostly in Europe and the USA. The market share of organic food is about $2 \%$ in total food marketing value of worldwide and of the organic food marketing value, organic livestock products portioned $17 \%$ in the USA. The organic livestock products are primarily marketed at Supermarket (Europe), Health and Natural Food store(USA). Concerning international trade, it is very little. But it is increasing among the developed counties of Europe. In the future, the production of organic livestock products will be rapidly increased in South America, Middle East and Oceania, but the growth rate will be limited due to its expensive price, lack of marketing-infra and different regulation system. Most of developed countries drive organic farming policy strongly as the strategic means of rural development, diversifying agriculture system and environmental improvement.
\end{abstract}

(Key words : Organic livestock, Organic food, Marketing, Consumption)

\section{I . 유기축산물 생산과 소비}

\section{1. 식품시장에서의 위치}

세계의 유기농가수는 1999년 약 19만호에서 2001년 약 25만호로 증가하였다. 대륙별 유기 농가 분포는 유럽, 북미, 남미가 각각 57.9 , $15.5,13.9 \%$ 로 이들 3 개 대륙이 전체의 약 $90 \%$ 를 점하고 있다(Santucci, 2002).

유럽의 유기농 수는 1985년 약 8천호에서 2001년 142천호로 급격히 증가하였다. 유기농 수와 유기경작지 면적은 이탈리아가 가장 많고 독일은 유기식품 판매액이 250백만 유로로 유
럽에서 가장 큰 시장을 형성하고 있다. 국민 1 인당 유기제품 소비량은 덴마아크와 스위스가 가장 높다. 유럽 전체의 유기경작 면적과 유기 식품 시장 점유율은 1 2\%에 이른다(Hermansen, 2003). 주요 소비국은 오스트리아, 덴마아크, 독 일, 영국 등이며 주로 우유, 쇠고기, 돼지고기 가 소비되고 있다. 유기축산물 시장점유율은 대체로 오스트리아, 덴마아크가 높고 품목별로 는 우유, 양고기, 쇠고기 순으로 높으나 전체적 인 점유율은 낮은 편이다(Table 1). 이는 유기 축산물에 대한 소비자의 인식과 현실간의 괴 리, 국가 또는 인증주체간의 기준차이, 표시방 법의 불명확성, 높은 가격 등 소비 장애 요인

Corresponding author:D. H. Kim, Animal Products and Processing Division, National Livestock Research Institute, 564 O-mockchun-dong, Kwonsun-gu, Suwon 441-350, Korea.

Tel : 031-290-1684. Fax : 031-290-1697. E-mail : kd8485@rda.go.kr 
Table 1. Market share(\%) of organic livestock products in the EU in 2000 (Modified from Hamm et al., 2002)

\begin{tabular}{lcccccc}
\hline \multicolumn{1}{c}{ Country } & Milk & Beef & Sheep & Pork & Poultry & Eggs \\
\hline \hline Austria & 7.7 & 3.5 & 5.9 & 0.5 & 0.7 & 2.7 \\
Belgium & 1.6 & 0.8 & 1.0 & 0.1 & 0.3 & 0.6 \\
Denmark & 13.1 & 3.0 & $*$ NA & 1.2 & 1.5 & 11.9 \\
Finland & 8.6 & 1.0 & 7.7 & 0.9 & 0.0 & 2.3 \\
France & 0.9 & 0.4 & 0.3 & 0.1 & 0.3 & 2.2 \\
Germany & 1.3 & 3.1 & 2.4 & 0.6 & 0.6 & 1.9 \\
Italy & 0.5 & 0.1 & NA & 0.0 & 0.4 & 0.6 \\
Luxemburg & NA & 0.6 & 1.4 & 0.8 & NA & NA \\
Netherlands & 1.6 & 0.8 & NA & 0.5 & 0.3 & 2.5 \\
Sweden & 1.8 & 1.0 & 1.7 & 0.4 & 0.0 & 2.1 \\
UK & 1.1 & 0.4 & 0.3 & 0.2 & 0.2 & 2.5 \\
\hline
\end{tabular}

Note : * NA : Not applicable.

이 있기 때문으로 분석되고 있다(Brennan et al., 2003).

미국의 유기산업은 1997년 이후 매년 $17 \%$ 내외의 성장을 해왔으며 2005년 판매액은 13,800 백만불에 이른다. 그 중 유기식품의 비 중이 가장 크며 연평균 성장률은 $16.2 \%$ 판매 액은 13,800 백만불에 이른다. 이는 전체 식품 판매액의 2.5\%에 해당하며 1997년 이래 15 $21 \%$ 의 성장율을 보였다(Table 2). 전체 유기식 품 판매액에서의 축산물의 비중은 약 $17 \%$ 수
준이다. 전체 유기식품의 2005년 판매성장률은 $16.2 \%$ 이었으나 유기축산물의 경우 낙농 23.6, 육 류 55.4\%로 매우 높은 성장률을 보였다(Table 3).

남미의 유기축산은 조방적 사육환경, 넓은 면적의 초지, 유기사료 공급능력 등을 고려할 때에 생산 잠재력이 크다(Yussefi and Willer, 2003). 아르헨티나의 경우, 1998년 기준으로 유 기쇠고기는 268톤이 생산되었고 약 $80 \%$ 가 유 럽으로 수출되었다. 유기축산물 소비량은 우유, 치즈, 가금육 및 계란이 각각 15 메가 리터, 4

Table 2. Organic foods consumer sales and penetration in USA (OTA, 2006)

\begin{tabular}{ccccc}
\hline & $\begin{array}{c}\text { Organic Food } \\
(\text { \$Mil) }\end{array}$ & $\begin{array}{c}\text { Organic Food } \\
\text { Growth (\%) }\end{array}$ & $\begin{array}{c}\text { Total Food } \\
\text { Sales (\$Mil) }\end{array}$ & $\begin{array}{c}\text { Organic } \\
\text { Penetration (\%) }\end{array}$ \\
\hline \hline 1997 & 3,594 & $*$ NA & 443,790 & 0.81 \\
1998 & 4,286 & 19.2 & 454,140 & 0.94 \\
1999 & 5,039 & 17.6 & 474,790 & 1.06 \\
2000 & 6,100 & 21.0 & 498,380 & 1.22 \\
2001 & 7,360 & 20.7 & 521,830 & 1.41 \\
2002 & 8,635 & 17.3 & 530,612 & 1.63 \\
2003 & 10,381 & 20.2 & 535,406 & 1.94 \\
2004 & 11,902 & 14.6 & 544,141 & 2.19 \\
2005 & 13,831 & 16.2 & 556,791 & 2.48 \\
\hline
\end{tabular}

Note : * NA : Not applicable 
Table 3. Organic food market sales and growth in USA (OTA, 2006)

\begin{tabular}{lrc}
\hline \multicolumn{1}{c}{ Organic Food Categories } & $\begin{array}{r}\text { Sales } \\
(\$ \mathrm{MMil})\end{array}$ & $\begin{array}{c}\text { Growth in } \\
\text { 2005(\%) }\end{array}$ \\
\hline \hline Dairy & 2,140 & 23.6 \\
Bread \& Grains & 1,360 & 19.2 \\
Beverages(incl. non-dairy) & 1,940 & 13.2 \\
Fruit \& Vegetables & 5,369 & 10.9 \\
Snack Foods & 667 & 18.3 \\
Packaged/Prepared Foods & 1,758 & 19.4 \\
Sauces/Condiments & 341 & 24.2 \\
Meat/Fish/Poultry & 256 & 55.4 \\
Total Org Food Consumer Sales & 13,831 & 16.2 \\
\hline
\end{tabular}

천 킬로그램, 120 천 킬로그램, 7천 다스이었다. 이는 1997년 대비 $40 \sim 60 \%$ 가 증가한 것이다 (FAO, 2002). 브라질의 유기축산물 생산은 대략 연간 $25 \%$ 내외의 높은 성장률을 보이고 있다. 1999년 현재 유기쇠고기, 돼지고기가 생산되고 있고 유기가금육, 계란, 우유 또한 급속히 성장 하고 있다. 1999년 말 기준 유기닭고기, 계란, 우유생산량은 각각 550천 수, 17천 다스, 1.6천 리터로 보고되고 있다(FAO, 2002).

이와 같이 유기농업이 범세계적으로 발달하 게 된 원인은 단순히 농업에 국한되어 있는 것 은 아니다. 그것은 사회전반에 걸쳐 일어나고 있는 변화들이 농업에 투영된 결과이다. 유기 농업은 기본적으로 주류 농업에 대한 비판과 현대적 기술을 바탕으로 한 인간과 자연과의 생태학적 불균형에 대한 회의에서 출발한다 (Michelsen. 2001). 이와 같은 비판과 회의는 정 치적, 사회적 관심사항이 되었고 국가는 이에 대한 대안으로서 유기농업을 도입하게 되었다.

우리나라는 2001년 7월 친환경육성법시행규 칙에 유기축산규정을 제정하고 2005년 최초로 이 기준에 의해 인증된 유기축산물을 출시하였 다. 2007년 2월 현재 53개 농가가 유기인증을 받아 유기축산물을 생산하고 있다. 우리나라 유기축산은 이제 시작단계이다. 환경이 다르기 는 하나 선발국들이 안고 있는 문제들이 시장
에 이미 나타나고 있거나 나타날 것으로 예측 되고 있다.

이 총설은 선발국의 유기축산물 소비시장이 당면하고 있는 문제와 이 분야에 접근하는 방 법에 대해 살펴보고 앞으로 우리나라 유기축산 물 시장이 나아갈 방향정립에 필요한 자료를 제공하는 데에 그 목적이 있다.

\section{2. 유통구조}

유기농업 초창기에는 생산물을 생산자가 소 비자에게 직접 유통하였다. 이와 같은 판매방 법은 유기식품 판매량이 증가함에 따라 수퍼마 켙을 통해 판매하는 방식으로 전환되는 추세에 있다.

유럽의 경우 덴마아크, 스웨덴, 오스트리아, 스위스가 전형적으로 이 방식을 취하고 있다. 덴마아크, 스위스, 오스트리아는 전체 유기식품 의 약 60 70\%가 수퍼마켙에서 판매되고 있다. 네덜란드와 독일의 유기식품 수퍼마켙 판매율 은 약 20 25\% 수준이다. 반면, 독일과 프랑스 는 소비자에게 직접 판매하는 비율이 20 30\% 로 다른 나라에 비해 높다(ITC, 1999).

최근 들어서는 대규모 체인점이 유기식품 판 매에 가세하고 있다. 영국은 유기식품의 $80 \%$ 가 여러 종류의 소매점을 통해 판매되고 있다. 이 들 중 대규모 체인점인 Sainsbury와 Tesco는 주 요한 유기식품 판매처로 부상하고 있다. 이들 체인점은 영국 유기식품의 $27 \%$ 를 판매하고 있 다. 따라서 대규모 체인점의 유기식품에 대한 태도 여하에 따라 유기식품 판매 잠재력이 영 향을 받는 구조로 변하고 있다(Harris et al., 2003).

오스트리아의 유기식품 판매구조는 유럽의 다른 나라와 다소 상이하다. 오스트리아는 유 기식품을 주로 공공매점(public canteen)에서 판 매하고 있다. 이 매점은 정부가 운영하고 있으 며 1997년 설치한 이래 2003년 현재 80여개의 공공매점(병원, 학교, 군대 등의 구내매점)이 운 영되고 있다. 정부는 정책적으로 이 공공매점 에서 전체 식품판매량의 $25 \%$ 를 유기제품으로 판매토록 의무화하고 있다. 공공매점에서의 연 
간 유기식품 판매액은 2003년 기준, 30백만 유 로에 달한다. 주요 판매제품은 우유, 낙농품, 쇠고기, 빵, 과일, 야채 등이다. 전체 유기쇠고 기의 $27 \%$, 유기우유의 $10 \%$ 가 이 공공매점에서 판매되고 있다(Wlcek et al., 2003).

미국의 유기식품은 주로 세 종류의 경로 즉 자연식품 판매점(Natural Food Store), 일반식품 판매점, 생산자 직거래를 통해 유통된다. 유기 식품 판매처별 비중은 일반 식료품점 49 , 자연 식품 판매점 $48 \%$ 로 추정되고 있다. 또한 전체 유기식품의 $13 \%$ 가 Walmart나 Cosco 같은 대형 할인점에서 판매되고 있다. 유기축산물 중 유 기육류와 가금육은 건강식품 전문매장 소위 Health and Natural-Food(HNF)에서 전체의 78\% 가 판매되고 있다. 대규모 수퍼마켙에서의 판 매량 또한 증가추세에 있으며 판매 점유율은 $15 \%$ 내외이다(Wheatley, 2003).

\section{3. 국제교역 동향}

현재의 무역통계는 유기제품과 일반제품을 구분하여 발표하고 있지 않다. 유기제품 및 일 반제품을 여덟 자리의 동일한 HS 코드에 의해 관리하고 있다. 따라서 유기식품에 대한 믿을 만한 무역통계를 얻기가 어렵다. 이와 같은 문 제를 해결하기 위해 현재 UN 통계국 산하의 Euro 통계부는 유기식품코드를 따로 추가(아홉 자리 코드 신설)할 것을 검토하고 있다.

현재 국가간의 유기축산물 교역은 개발국 특 히 유럽국가 사이에서 점차 활성화하는 추세에 있다. 예를 들어 덴마아크는 자국 생산 유기돼 지고기의 $80 \%$ 를 영국에 수출하고 있다. 그러나 $\mathrm{EU}$ 외의 국가 특히 개발국과 개발도상국 간의 교역량은 극히 미미하다. 그 원인은 개발도상 국의 생산량 자체가 적어 수출여력이 없고 국 가간의 인증기준 차, 효과적인 검증수단 미비 에 따른 개발도상국 축산물에 대한 개발국의 불신, 특정 가축질병 발생과 관련한 무역장벽, 일부 개발국의 수입물량에 대한 쿼터제 적용, 수입관세 등으로 지적되었다(Harris et al., 2003).

유럽의 유기축산물 주요 수입국은 벨지움, 룩셈브르크, 네델란드, 영국이다(Table 4). 덴마
아크, 오스트리아, 핀란드 및 스웨덴은 대체로 자급자족하였다. 전체적으로 $\mathrm{EU}$ 는 유기쇠고기, 양고기, 염소고기에 관한한 수입국이며 이들 품목을 소량이기는 하나 주로 동유럽과 아르헨 티나, 호주, 뉴질랜드, 우르구아이에서 수입하 고 있다. 반면 유기우유, 치즈, 유기돼지고기, 닭고기, 계란을 수출하고 있으며 주요 수입국 은 주로 EFTA(European Free Trade Association) 국가이다.

유럽으로 유기축산물을 수출하는 국가 중 뉴 질랜드는 공격적 마케팅과 유기축산에 대한 전 문성을 구비하여 유기축산물 수출에 괄목할 만 한 성장을 보이고 있다. 뉴질랜드의 유기산업 총 생산액은 2002년 현재 140 백만불이며 이중 수출액은 70 백만불에 이른다.

\section{4. 앞으로의 전망}

2006년 현재 세계의 유기농지면적은 31백만 $\mathrm{ha}$ 에 달하며 매년 약 5 백만 ha가 증가하고 있 다. 증가면적의 대부분은 목초지로 나타나고 있다. 국가별 유기경작지 면적은 호주가 12.1, 중국과 아르헨티나가 각각 약 $3,2.8$ 백만 ha 순 이다. 세계 유기농지 면적 대비 대륙별 면적비 중은 오세아니아 39, 유럽 29, 라틴아메리카 20 , 아시아 13 , 북미 4 , 아프리카 $4 \%$ 이다. 세계 시장의 유기제품 판매액은 2004년 기준 27,800 백만불에 이르며 판매액의 대부분은 유럽과 북 미시장이 점하고 있다(Helga and Minou, 2006).

이와 같은 성장세는 각국 정부의 집중적 지 원과 관련단체 증가 및 활성화로 당분간 유지 할 것으로 전망된다. 유기제품 판매시장 또한 범세계적으로 팽창할 것으로 전망된다. 이와 같은 성장은 유럽과 북미, 브라질, 중동, 오세 아니아 시장이 주도할 것으로 전망하고 있다. 아울러서 가까운 장래에 Tyson Food와 같은 기 존의 거대 식품업체가 유기식품 시장에 진출할 것으로 보인다.

1990년대 유럽의 유기식품시장은 연평균 $7.8 \%$ 의 성장률을 보였다. 2001년에 발표한 국 가별 성장전망치는 덴마아크 $1.5 \%$ 에서 영국 $11 \%$ 에 이르기까지 그 차가 크나 1990년대에 
Table 4. Imports of organic livestock products into the EU in 2000(Modified from Hamm et al., 2002)

\begin{tabular}{lrrrrrr}
\hline \multicolumn{1}{c}{ Country } & $\begin{array}{c}\text { Milk } \\
(\mathrm{t})\end{array}$ & $\begin{array}{c}\text { Beef } \\
(\mathrm{t})\end{array}$ & $\begin{array}{c}\text { Sheep } \\
(\mathrm{t})\end{array}$ & $\begin{array}{c}\text { Pork } \\
(\mathrm{t})\end{array}$ & $\begin{array}{c}\text { Poultry } \\
(\mathrm{t})\end{array}$ & $\begin{array}{c}\text { Eggs } \\
(\text { million })\end{array}$ \\
\hline \hline Austria & 1,000 & 0 & 0 & $*$ NA & NA & 0 \\
Belgium & 6,000 & 600 & NA & NA & NA & 3 \\
Denmark & 0 & 0 & 0 & 0 & 0 & 0 \\
Finland & 30 & 0 & 0 & 0 & 0 & 0 \\
France & 25,000 & 800 & NA & NA & 0 & 0 \\
Germany & 15,000 & 400 & 30 & 400 & 200 & 50 \\
Greece & NA & NA & NA & NA & 0 & 0 \\
Ireland & NA & NA & NA & NA & NA & NA \\
Italy & 12,000 & 200 & NA & 110 & NA & 15 \\
Luxemburg & 75 & 15 & 1 & 5 & 5 & 1 \\
Netherlands & 2,500 & 690 & 225 & 275 & 80 & 12 \\
Portugal & NA & NA & NA & NA & NA & NA \\
Spain & NA & NA & NA & NA & NA & NA \\
Sweden & 20 & 0 & 0 & 0 & 0 & 0 \\
UK & 22,000 & 496 & 18 & 750 & 700 & 5 \\
Total & 83,625 & 3,201 & 274 & 1,540 & 985 & 86 \\
\hline
\end{tabular}

Note : * NA : Not applicable.

비해 그 성장률이 다소 낮을 것으로 전망하였 다. 미국은 1990 년대에 $20 \%$ 내외의 고속성장을 하였으며 이와 같은 추세는 2005년까지 지속되 었다. 그 이후 2010년까지 매년 9-16\% 성장할 것으로 예측하고 있다(OTA, 2006).

그러나 Harris(2003)에 의하면 일부 유기식품 에서 공급과잉 현상이 나타나고 있으며 이에 따라 농가가 받는 프리미엄이 줄어들고 있다고 하였다. 이와 같은 견해를 뒷받침할 수 있는 자료가 스칸디나비아의 육류생산자보고서에 나 타나 있다. 이 보고서는 스칸디나비아 국가의 유기축산물 성장률이 정체되어 있으며 이를 해 소하기 위해서는 수출에 주력해야 할 것으로 지적하였다. 1990 년 말 기준 이 지역의 유기육 류 성장률은 20\%이었으나 2002년은 9.2\% 성장 에 그쳤다. 이는 최근 들어 유기육류에 대한 소비자의 수요가 안정세를 보이고 있기 때문으 로 분석하였다. 영국도 국내 유기육류생산은
지속적으로 증가하고 있으나 수요가 정체되어 공급과잉 현상이 발생하고 있다. 이와 같은 수 요를 초과한 공급으로 유기쇠고기와 양고기의 $20 \%$ 가 일반육류로 판매되고 있는 실정이다.

유기축산물교역과 관련해서, $\mathrm{EU}$ 는 수입은 증 가할 것이나 다음과 같은 요인으로 해서 수입 증가 폭이 크지 않을 것으로 전망된다. 그 이 유는 첫째, $\mathrm{EU}$ 내에서의 유기축산물 생산이 증 가하여 유기식품분야에서의 무역역조 현상이 감소할 것이다. 둘째, 제품 역추적, 품질, 안전 성 및 환경에 대한 관심증가로 소비자들은 해 당지역에서 생산된 제품을 선호할 것이다. 셋 째, 판매상들은 첫째와 둘째의 이유로 그 지역 에서 생산된 제품판매를 더 선호할 것으로 보 고되고 있다(Harris et al., 2003). 미국 또한 국 가간 유기축산물 인증기준 차, 점차 강화되고 있는 안전성과 관련된 규제 등으로 가까운 장 래에 개발국 또는 개발도상국으로부터 유기축 
산물을 수입할 가능성은 극히 낮은 것으로 전 망된다.

\section{․ 소비분야에서의 해결과제}

\section{1. 높은 가격}

유기축산물에 대한 수요가 증가하고 있으나 판매량은 일반축산물과의 가격차가 커 제한되 고 있다. 축산물에서의 이와 같은 가격차는 다 른 유기식품에 비해 더 큰 것이 특징이다.

Hamm 등(2002)은 EU 국가별 유기축산물 가 격 프리미엄을 분석하였다(Table 5). EU 국가 중 특히 오스트리아, 벨지움, 독일, 영국의 유 기축산물 프리미엄이 높았으며 덴마아크, 핀란 드, 아일랜드와 스웨덴은 서로 비슷한 정도의 프리미엄을 형성하고 있다.

이와 관련하여 Park과 Lohr(1995)는 유기식품 의 가격 프리미엄은 시장에서 전형적으로 나타 나는 현상이며 일반식품에 비해 최고 $250 \%$ 이
상의 가격을 받고 있는 것으로 발표하였다. Richman(2000)도 신선 또는 가공 유기식품의 가격 프리미엄의 범위는 5-450\% 이었으며 평균 $30 \%$ (수퍼마켙 기준)로 보고한 바 있다.

이와 같은 높은 가격은 유기축산물 소비를 제약하는 주요한 요소로 작용하고 있다. Cooke (2002)의 보고에 따르면 유기식품을 구매하지 않은 소비자의 $53 \%$ 가 가격 때문이라 하였다. 또한 Brennan 등(2003)은 소비자 소득수준에 따 른 유기식품 구매의향을 조사한 결과, 중 - 저 소득층의 $47 \sim 50 \%$ 가 비싼 가격 때문에 유기식 품을 구매하지 못하는 것으로 나타났다. 따라 서 유기식품의 높은 가격은 저 소득층에서의 소비창출을 방해하는 요인이 되고 있다고 하였 다. 소비자 조사결과에 나타난 유기축산물의 적정 프리미엄은 10(Richman, 2000) 37\% (Jolly, 1991)이었다.

\section{2. 유통 인프라 미비}

Table 5. Consumer price premium for organic livestock products in the $\mathrm{EU}$ in 2000 (Modified from Hamm et al., 2002)

\begin{tabular}{lcccccccc}
\hline \multicolumn{1}{c}{ Country } & $\begin{array}{c}\text { Rump } \\
\text { steak (\%) }\end{array}$ & $\begin{array}{c}\text { Minced } \\
\text { beef (\%) }\end{array}$ & $\begin{array}{c}\text { Lamb } \\
\text { chops (\%) }\end{array}$ & $\begin{array}{c}\text { Pork } \\
\text { cutlet (\%) }\end{array}$ & $\begin{array}{c}\text { Minced } \\
\text { pork (\%) }\end{array}$ & $\begin{array}{c}\text { Whole } \\
\text { chicken (\%) }\end{array}$ & $\begin{array}{c}\text { Milk } \\
(\%)\end{array}$ & $\begin{array}{c}\text { Eggs } \\
(\%)\end{array}$ \\
\hline \hline Austria & 87 & 23 & 96 & 50 & 68 & 142 & 27 & 23 \\
Belgium & 54 & 78 & 92 & 95 & 78 & 155 & 69 & 21 \\
Denmark & 5 & 47 & $*$ NA & 27 & 49 & 267 & 18 & 47 \\
Finland & 25 & 47 & NA & 27 & 25 & NA & 48 & 109 \\
France & 86 & 41 & 22 & 80 & 59 & 56 & 35 & 45 \\
Germany & 29 & 47 & 60 & 65 & 48 & 111 & 56 & 53 \\
Greece & NA & NA & NA & NA & NA & NA & 85 & 140 \\
Ireland & 79 & 20 & 26 & 45 & NA & 59 & 18 & 39 \\
Italy & 50 & NA & 14 & 13 & 92 & 191 & 31 & 50 \\
Luxemburg & 70 & NA & 37 & 90 & 92 & 101 & 45 & 133 \\
Netherlands & 9 & 54 & NA & 26 & 81 & 140 & 33 & 94 \\
Portugal & NA & NA & NA & NA & NA & NA & 186 & 83 \\
Spain & NA & NA & NA & NA & NA & NA & NA & NA \\
Sweden & 16 & 22 & 22 & 32 & NA & 45 & 22 & 59 \\
UK & 75 & 61 & 78 & 14 & NA & 102 & 59 & 36 \\
\hline
\end{tabular}

Note : * NA : Not applicable. 
유기축산물 유통과 관련하여 당면하고 있는 문제는 세계 각국 대부분의 축산물 대량판매업 체가 공급자로부터 유기축산물을 직접 구매하 지 않고 있다는 데에 있다. 이는 상당수의 생 산자들이 판매상이 요구하는 서비스의 수준이 나 제품형태를 맞추지 못하고(Richman, 2000) 판매상에게 유기축산물의 특성을 충분히 설명 하지 못하기 때문(Grannis and Thilmany, 2001) 으로 지적되고 있다.

따라서 대부분의 신규 진입 생산자는 판매업 자와 거래관계를 개설하는 데에 많은 비용을 지불하고 있다. Lohr와 Semali(2000)는 유기산업 의 발전방향과 관련하여 유기식품에 대한 소비 자의 올바른 인식을 유도하기 위해서는 판매장 직원의 역할이 매우 중요하며 이는 적절한 교 육을 통해서 달성할 수 있다고 하였다. 아울러 서 이들 직원이 소비자에게 프리미엄 수준에 대한 분명한 이유를 설명하여야 한다고 하였 다.

이에 따라 판매시장에서 유기제품 판매하기 위한 새로운 판매 방식들이 도입되고 있다. 미 국 시장의 경우 생산자가 General Mills (Minnesota), Dannon (New York) 등과 같은 대규모의 조합을 결성하여 시장진입에 성공하고 있다(Dimitri and Richman, 2000). 이외에도 생산자가 그 지 역의 식당이나 소매상과 계약하여 생산한 축산 물을 직접 공급하거나 인터넷을 이용하여 보다 더 넓은 지역에 제품을 판매하고 있다. 인터넷 을 이용한 판매는 생산농가 보다는 전국적 유 통망을 보유한 대규모 구매자 또는 조합에서 활성화되고 있다. 특히, 미국의 유기돼지고기를 유통하는 대규모 업체 즉 Niman Ranch (California), Organic Valley Family of Farms (Wisconcin), Applegate Farm(New Jersey)에서 높 은 판매실적을 보이고 있다. 그러나 일부 생산 자는 인터넷에 의한 판매비중이 크지 않은 반 면 독자적 웹 구축에 비용이 많이 드는 것을 문제로 지적하고 있다.

\section{3. 유사 유기축산물의 시장진입}

유럽의 주요한 수퍼마켙 체인망인 EUREP은
GAP(Good Agriculture Practice) 정착을 촉진하 기 위해 일반축산물에 대한 구매기준을 WTO/ $\mathrm{WHO}$ 가 권장하고 있는 수준 이상으로 상향조 정한 바 있다. 이는 소비자의 축산물에 대한 품질, 안전성과 관련한 요구사항을 상당부분 반영한 것으로 유기축산물의 기본개념과 유사 성이 많다. 북미 대륙의 경우도 유기축산물 이 전에 이미 'Natural' 축산물이 판매되고 있고 시 장에서의 판매비중이 유기축산물보다 높다. 이 외에도 '무 항생제 사육' ‘무 홀몬제' 등의 축 산물도 시장에 나타나고 있다. 이와 같이 유기 축산물과 개념이 비슷한 축산물의 출현은 시장 에서 소비자의 혼돈과 불신을 초래하고 있다. 이는 궁극적으로 유기축산물에 대한 소비자의 수요 감소로 이어질 개연성이 크다.

이에 대한 해결수단으로서 기존의 라벨링 시 스템을 개선하여 차별성을 강화하는 방안이 검 토되고 있다(Van Ravenswaay, 1996). 또한 유기 생산농가가 서로 협조하여 유통체널과 라벨을 감시하는 시스템 구축이 필요한 것으로 보고되 었다(Richman, 2000). 결론적으로 유기축산물의 차별화는 통합된 라벨을 유지하느냐에 따라 달 라진다. 그러나 라벨링 문제가 해결된다 하더 라도 생산자는 그들이 시장진입 시 선택한 라 벨링, 생산과 관련된 약속사항에 대한 기록을 유지하여야 하며 이에 따른 비용도 고려할 필 요가 있다. 라벨링과 기록유지 비용은 증가하 는 추세에 있다(Van Ravenswaay and Blend, 1997). 최근에는 이와 같은 문제점을 해소하기 위해 유럽은 전역에서 통용되는 단일한 라벨링 사용을 검토하고 있다.

\section{4. 국가간 인증기준 차이}

현재 국제적으로 근간이 되고 있는 유기축산 기준은 $\operatorname{Codex(2001)}$ 기준, $\operatorname{IFOAM(1996)}$ 기준이 다. 이들 기준은 최소한의 규범만을 규정하고 있어 세부기준에 있어서는 국가 또는 인증주체 에 따라 차이가 많다. 앞서 언급한 바와 같이 일부 개발국 특히 유럽을 중심으로 유기식품 수요정체 현상이 나타나고 있다. 이들 국가는 남아도는 유기축산물을 다른 나라에 수출을 시 
도하고 있다. 또한 개발도상국가 즉 브라질, 아 르헨티나 등에서도 유기축산이 시작단계에 있 으며 이들 국가도 개발국에 유기축산물을 수출 하는 데에 지대한 관심을 나타내고 있다.

그러나 유기축산물의 국가간 교역은 아직 크 게 활성화되고 있지 않다. 그 이유는 첫째, 아 직 유럽이나 미국의 유기축산물 시장에서 수요 와 공급의 불균형이 크지 않으며 둘째, 개발도 상국가의 유기축산업 발달이 미미하고 셋째, 각국의 기준이 상이하여 상대국의 유기축산기 준을 불신하고 있기 때문이다.

유럽은 유기축산법(Council Regulation 1804/ $99,1999)$ 을 2000년에 제정하여 시행해 오고 있 다. 이 법은 유럽에서 판매되는 유기축산물의 생산, 라벨링, 판매에 대한 최소한의 기준을 제 시하고 있다. 따라서 유럽의 각국은 이 법을 독자적으로 해석하여 각국의 기준을 설정, 운 용하고 있다. 이와 같은 차이로 해서 $\mathrm{EU}$ 의 유 기식품에 대한 라벨링 체계는 국가마다 다르 다. 일부국가는 국가기관이 인증하는 반면 또 다른 국가는 민간기관이 인증하고 있다(스웨덴 KRAV, 네덜란드 Skal, 영국 Soil Association). 이에 따라 유럽은 2000년부터 유럽에서 통용될 수 있는 로고를 제작하여 사용토록 권장하고 있으나 이를 활용하는 국가는 거의 없는 실정 이다. 2005년 12월 유럽위원회는 95\% 이상의 유기요소를 포함한 제품에 대해 'EU-organic'로 고 사용을 의무화하였다.

미국은 1990년 Organic Foods Production $\mathrm{Act}(\mathrm{OFPA})$ 를 제정하였다. OFPA가 규정하고 있 는 바는 크게 1) 유기제품 판매기준 설정 2) 유기제품 기준에 대한 소비자의 신뢰도 제고 3) 주간 유기제품 거래활성화이다. USDA National Organic Standard는 종전 주별 유기기 준을 통합하여 2002년 10월 21일에 발효되었 다.

$\mathrm{EU}$ 와 미국은 국가가 인증한 기관을 통하여 유기농가와 관련업계 종사자를 인증하고 있다. 그러나 EU와 미국의 유기축산물인증기준은 동 일하지 않다. 또한 유럽 내에서도 국가간 인증 기준이 일치하지 않고 있는 실정이다. 이는 회 원국들 간에 인증기관을 인증하는 방법과 관리
방식에서 상당한 차이가 있기 때문이다. 따라 서 국가 간에 인증시스템에 차이가 많다. 결론 적으로 주요한 유기축산물 판매시장인 유럽과 북미, 또는 유럽국가간에 상호 수용할 수 있는 기준에 의해 유기제품을 인증하고 있지 않다.

국가간 인증기준 통일과 관련하여 Elm Farm Research Center(1999)는 '전 유럽에서 동등하게 통용되는 기준을 제정하고 시행하는 일은 백치 나 하는 일'(the setting and policing of organic farming standards throughout Europe is idiosyncratic)이라 하여 적용 가능한 통일된 기준제 정이 쉽지 않음을 시사하였다(Brennan et al., 2003). Desai(2001)도 국제규정과 조화를 이루지 않은 기준은 공허한 것이며 소비자의 유기개념 에 대한 혼란을 초래하고 이로 인해서 이 부문 이 소비자로부터 외면당하는 결과로 나타날 수 있음을 경고하였다.

\section{III. 선발국들의 접근방법}

$\mathrm{EU}$ 또는 유럽각국은 농촌사회 발전, 농업생 산방식의 다양화, 농업분야에서의 환경부하 경 감 등을 위한 수단으로서 유기농업을 유지, 발 전시켜 왔다. 정책적 중점 포인트는 각국의 형 편에 따라 다르다.

스페인(Trujillo, 2000)과 오스트리아(Eder et al., 2000)는 유기농업을 산간지역의 경제, 생활 환경 활성화에 중점을 두어 시행하고 있다. 그 리스의 경우(Argyris, 2001)는 1) 자연자원의 고 갈방지 2) 지역 유전자원 활용성 증진 3) 특정 지역의 인구감소 방지 4) 농업시스템을 지역 생태보호시스템으로의 전환 5) 2차 가공산업 발달에 의한 피해로부터 농가보호 및 삶의 질 향상에 그 목표를 두고 있다.

덴마아크는 집약사육에 따른 국지적 영양과 잉 해결수단으로서 유기농업을 중요시하고 있 다(MFAF, 2001). 또한 유기농업을 환경개선을 위한 정치적 수단으로 활용하고 있다. 유기농 가 수는 개활지의 생물학적 다양성을 나타내는 지표로 이용되고 있다. 덴마아크 정부가 제정 하여 운용 중인 Action Plan $\square$ 에서는 '유기농 업은 바람직한 환경유지에 도움이 되므로 이에 
대한 대가를 지불해야 한다. 따라서 사회가 유 기농업으로 전환하는 농가나 유기농업 영위농 가에 공적 보조금을 지급하는 것은 정당하다, 고 하였다.

중부와 동유럽(CEE)의 유기농업은 다른 유럽 과 다른 이유로 발전일로에 있다. 경제체제의 변화로 이들 국가에서는 대규모의 국유농업에 서 투입이 작고 노동집약적인 소규모의 농업으 로 급격히 변화하였다. 그러나 이와 같은 변화 가 환경, 자연친화적이지는 않았다. $\mathrm{CEE}$ 국가 에서의 정책 입안자들이 유기농업에 관심을 갖 는 주요한 이유는 지역 $\mathrm{NGO}$ 의 압력, $\mathrm{EU}$ 가입 및 시장에서의 판매증가와 유기농업이 사회적 으로 가져다주는 이점 등이다. 주요국은 체코, 헝가리, 폴란드, 슬로바크이다. 이들 나라는 상 대적으로 유기농지 면적이 크고 유기제품판매, 검사, 인증시스템이 잘 발달되어 있다. 대부분 의 $\mathrm{CEE}$ 국가는 유기농에 대한 정부의 지원이 거의 없다. 그러나 $\mathrm{EU}$ 가입과 관련된 환경, 사 회적 요건을 충족하기 위해서는 이와 같은 관 행이 가까운 장래에 변할 것으로 보인다.

\section{IV. 시 사 점}

한국의 유기축산은 2001년 친환경육성법에 유기축산물 인증기준을 제정한 후 2005년 최초 로 유기인증 농가가 발생하였다. 2007년 2월 현재 53개 농가가 유기가축을 생산하고 있다. 축종별 인증농가 수는 산란계와 육계가 각각 18,11 개소이고 한우, 돼지, 젖소는 각 5 개소이 다. 이외에 육우, 산양이 인증을 받아 사육 중 에 있다. 사육규모는 산란계, 육계, 육우, 한우, 젖소, 돼지가 각각 $48,422,18,0.3,1.2,3.2$ 천 두(수)로 아직 이렇다 평가할 수준이 아니다.

한국의 유기축산은 시작단계이다. 따라서 생 산, 소비분야에 많은 문제점들이 나타나고 있 다. 우선 생산농가가 판매에 어려움을 겪고 있 다. 유기축산물 중 육계와 계란의 극히 일부만 이 대형유통업소에 납품되고 있고 그 외의 축 산물은 전문유통업소를 통한 회원제 유통에 판 매를 의존하고 있다. 판매처를 확보하지 못한 농가는 생산을 중단하거나 일반축산물로 판매
하고 있다. 대형 유통업소는 뜻은 있으나 공급 물량의 영세성, 사육방식과 관련한 사고발생 시 책임문제, 판매물량은 적은 반면 문제발생 시 이미지 훼손이 크다는 점 등을 우려하여 판 매에 아직 가세하고 있지 않다.

또한, 국내산 유기축산물의 높은 가격이 판 매저변 확대에 장애요소로 작용하고 있다. 농 촌진흥청 축산연구소에서 조사한 미발표 자료 에 의하면 우리나라 유기육류의 가격은 쇠고기 등심 100 천원 $/ \mathrm{kg}$, 돼지고기 삼겹살 35 천원 $/ \mathrm{kg}$, 닭고기 10 천원/수로 나타났다. 일반축산물에 비해 2 - 3배 높은 가격으로 판매되고 있다. 이 와 같이 국내산 유기축산물의 가격이 높은 이 유는 첫째, 유기사료 전량을 외국 주로 중국에 서 수입해서 사용하고 있어 사료 값이 고가이 고 둘째, 가축에 대한 유기사양기술이 정립되 지 않아 생산비가 높으며 셋째, 일부 마니아를 중심한 회원제 유통으로 시장에 경쟁가가 형성 되지 않기 때문으로 추정된다.

범세계적으로 유기축산물 소비는 빠르게 증 가하고 있다. 앞으로도 이와 같은 추세는 지속 될 것으로 전망된다. 우리나라의 유기축산도 현재의 생산량이 극히 적고 소비자의 식품안전 성에 대한 의식, 정부의 유기축산 육성의지 및 환경과 관련된 규제 강화 등 주변여건을 고려 할 때에 향후 비약적인 발전이 있을 것으로 전 망된다.

30년 이상의 유기농업역사를 가진 유럽도 전 체 식품판매액 중 유기식품의 비중이 $5 \%$ 를 넘 지 못하고 있다. 이는 앞으로의 우리나라 유기 축산물 시장이 넘어야할 산이 많음을 시사하고 있다.

유기축산 선발국의 사례에서 알 수 있듯이 우리나라 유기축산물 소비가 성공적으로 대중 화하기 위해서는 우선 유기축산물 생산, 유통, 소비 인프라가 빠른 시일 내에 갖춰져야 한다. 가장 시급한 것은 유기사료를 자급할 수 있는 기반을 확보하는 것이다. 유기사료 생산기반 없는 유기축산은 외국 유기축산물에 시장을 내 주는 결과로 나타날 것이다. 또 다른 시급한 문제는 유기축산물의 유통통로를 열어주는 것 이다. 현재의 생산되는 유기축산물, 특히 유기 
육류는 거의 전부 특정회원을 상대로 한 폐쇄 적 유통에 판매를 의존하고 있다. 따라서 정상 적인 가격이 형성되고 있지 않다. 유럽이나 미 국의 경우 유기육류의 $20 \%$ 정도가 일반유통체 인 즉 수퍼마겥에서 판매되고 있다. 유기축산 물 소비대중화를 위해서는 소비자의 제품에 대 한 접근성이 매우 중요하며 접근성은 일반유통 시스템을 활용하는 것이 가장 바람직하다.

아울러서 아직 평가하기는 이른 감이 있으나 높은 판매가격을 낮추는 노력이 필요하다. 이 는 생산비, 물류비용 절감을 통해 달성할 수 있다. 이를 위해서는 유기생산시스템 내에서의 생산비 증가요인에 대한 체계적인 접근이 있어 야 하고 생산자 간의 네트웍 구성 또는 조합결 성, 유명유통업체 또는 유기농산물 판매장과의 전략적 제휴 등이 필요하다.

유기축산 선발국들은 세계시장을 선점하기 위해 정책논리를 개발하고 재정적 지원을 아끼 지 않고 있다. 생산자에게 보조금을 지불함은 물론이고 판매를 위한 생산자조합, 생산자 네 트웍 결성 및 연구, 지도 분야에도 점점 더 많 은 재정적 지원이 이루어지고 있다. 우리나라 도 유기축산 인프라가 정착될 때까지 정부의 지속적이고 집중적인 논리개발과 지원이 필요 하다.

\section{V. 요 약}

세계 유기농가 수는 약 25만호에 달하며 세 계시장의 유기제품판매액은 27,800 백만불(2006) 에 이른다. 유기축산물 주요소비국은 EU 및 미 국이며 주요품목은 우유, 양고기, 쇠고기이다. $\mathrm{EU}$ 와 미국의 유기식품 시장점유율은 $2 \%$ 미만 이며 이중 유기축산물의 비중은 $17 \%$ (미국)이 다. 유기축산물의 주된 유통통로는 수퍼마켙(유 럽), 건강식품전문매장(미국)이며 Tesco, Walmart 등과 같은 대형체인점의 판매비중도 증가하는 추세이다. 국가간 유기축산물교역량은 극히 적 으며 주로 개발국 특히 유럽국가 간에 활성화 하고 있다. 앞으로의 유기식품시장은 남미, 중 동, 오세아니아를 중심으로 급성장할 것이다. 그러나 성장속도는 높은 가격, 유통인프라 미
비, 유사유기축산물의 시장진입, 국가간의 인증 기준차이 등에 의해 제한될 것이다. 유기축산 선발국들은 유기농업을 농촌사회의 발전, 농업 생산방식의 다양화, 환경개선 등을 위한 정책 적 수단으로 활용하고 있다.

\section{VI. 인 용 문 헌}

1. Argyris, V. 2001. Delegate speech. In: Proceedings: Organic Food and Farming. Towards Partnership and Action in Europe, Copenhagen, May 2001. Danish Ministry of Food, Agriculture, and Fisheries, Copenhagen, Denmark, p. 39.

2. Brennan, C., Gallagher, K. and McEachern, M. 2003. A review of the consumer interest in organic meat. Interna. J of Consumer Stud. 27: 381-394.

3. Codex Alimentarius Commission (CAC). 2001. Guidlines for The Production, Processing, Labelling and Marketing of Organically Produced Foods, CAC/GL32-1999, Rev-2001.

4. Cooke, M. 2002. Importing organic meat and dairy products and retail markets in the UK. Proceedings of a Symposium on Organic Markets for Meat and Dairy Products: Trade Countries for Developing Countries. Intergovernmental Group on Meat and Dairy Products. 19th Session, 27-29 August 2002. FAO, Rome, Italy, p. 16.

5. Council Regulation(EC) NO 1804/.1999. 1999. Supplementing Regulation (EEC) No 1804/1991 on Organic Production of Agricultural Products and Indications Referring Thereto on Agricultural Products and Foodstuffs to Include Livestock Production. Off. J. Eur. Communities, L222, p. 1-28.

6. Desai, R. 2001. Unfolding the organic maze : Lack of international regulations could stifle the organics market. In: http://just food-food.com/ features-detail.aspart=373.

7. Dimitri, C. and Richman, N. J. 2000. Organic Food Markets in Transition. Policy Studies Report No. 14. Henry A. Wallace Center for Agricultural 
and Environmental Policy, Greenbelt, Maryland, USA.

8. Eder, M., Kirner, L. and Zollitsch, W. 2000. Animal husbandry in alpine organic farmingregional diversity and critical obstacles in Austria. In: http://www.veeru.reading.ac.uk/organic/proc/eder. htm.

9. Elm Farm Research Centre. 1999. Evidence from Elm Farm Research Centre to the House of Lords Select Committee on the European Communities Sub-Committee Department of Agriculture, Fisheries and Foods, p. 4. EFRC, Berkshire, UK.

10. Food and Agriculture Organization. 2002. Market development for organic meat and dairy products: Implications for developing countries. Committee of commodity problems. International Group on Meat and Dairy Products. 19th Session, 27-29 August 2002. Rome, Italy.

11. Grannis, J. and Thilmany, D. 2001. Marketing opportunities for natural pork products: Defining the consumers who would purchase natural pork. J. Amer. Soc. p. 93-98.

12. Hamm, U., Gronefeld, F. and Halpin, D. 2002. Analysis of the European Market for Organic Food. Organic Marketing Initiatives and Rural Development. Vol. 1.

13. Harris, P. J. C., Browne, A. W., Barrett, H. R. and Gandiya, F. 2003. The Organic Livestock Trade from Developing Countries: Poverty, Policy and Market Issues. DFID Final Technical Report. School of Science and The Environment Coventry University, Priory Street Coventry CV1 5F13, UK.

14. Helga, W. and Minou, Y. 2006. The world of organic agriculture-statistics and emerging trends 2006. IFOAM, Bonn, Germany.

15. Hermansen, J. 2003. Organic livestock production systems and appropriate development in relation to public expectations. Livest. Prod. Sci. 80:3-15.

16. International Trade Center. 1999. Overview World Markets for Organic Food and Beverages. International Trade Center, UNCTAD/WTO, Geneva, Switzerland.
17. International Federation of Organic Agricultural Movement. 1996. Basic Standards for Organic Agriculture and Food Processing. 10th Edition. Sol, Bad Durchein, Germany.

18. Jolly, D. A. 1991. Differences between buyers and nonbuyers of organic produce and willingness to pay organic price premiums. J. Agribusiness. 9: 97-111.

19. Lohr, L. and Semali, M. 2000. Reconciling Attitudes and Behavior in Organic Food Retailing. Faculty Series 00-08. Dept of Agricultural and Applied Economics. University of Georgia, Athens, USA.

20. Ministry of Food, Agriculture and Fisheries. 2001. In: Proceedings: Organic Food and Farming Towards Partnership and Action in Europe, Copenhagen, May 2001. Danish Ministry of Food, Agriculture, and Fisheries, p. 25.

21. Michelsen, J. 2001. Recent development and political acceptance of organic farming in Europe. Sociol. Ruralis. 41:3-20.

22. Organic Trade Association. 2006. Manufacturer survey. In: hattp://www.ota.com/bookstore.html.

23. Park, T. A. and Lohr, L. 1995. Supply and demand factors for organic produce. Faculty series 95-02, Dept. of Agricultural and Applied Economics. University of Gorgia, Athens, USA.

24. Richman, N. J. 2000. The Natural Foods Market: A Natural Survey of Strategies for Growth. Policy Studies Report Number 12. The Henry A. Wallace Institute for Alternative Agriculture, Greenbelt, Maryland, USA.

25. Richman, N. J. 2000. The Growing Natural Foods Market: Opportunities and Obstacles for Mass Market Supermarkets. Working Paper WP 00-02. The Retail Food Industry Center, Dept of Applied Economics, University of Minnesota, St. Paul, USA.

26. Santucci, F. M. 2002. Market Issues in Organic Meat and Dairy Markets. The Symposium on Organic Markets for Meat and Dairy Products. FAO, Rome, Italy. 
27. Trujillo, R. G. 2000. Organic livestock production in Spaim. In: Proceedings of the Second NAHWOA Workshop, http://www.veeru.reading.ac. uk/organic/proc/garcia.htm.

28. Van Ravenswaay, E. O. 1996. Emerging Demands on Our Food and Agricultural System: Developments in Environmental Labeling. Staff Paper Series No. 96-88. Dept of Agricultural Economics, Michigan State University, East Lansing, USA.

29. Van Ravenswaay, E. O. and Blend, J. R. 1997. Use of Ecolabeling to Encourage Adoption of Environmental Technology in Agriculture. Staff Paper No. 97-19. Dept of Agricultural Economics,
Michigan State University, East Lansing, USA.

30. Wheatley, W. P. 2003. The natural and organic pork market: A sustainable niche for small-scale producers? A review and analysis of the evidence. Amer. J. of Altanative Agric. 18:18-26.

31. Wleck, S., Eder, M. and Zollitsch, W. 2003. Organic livestock production and marketing of organic animal products in Austria. http://www. wiso.boku.ac.at/fileadmin.

32. Yussefi, M. and Willer, H. 2003. The World of Organic Agriculture 2003-Statistics and Future prospects. IFOAM, Tholey-Theley, Germany.

(접수일자 : 2006. 11. 6. / 채택일자 : 2007. 4. 17.) 